\title{
Interaction Between XRCC1 Gene Polymorphisms and Obesity on Susceptibility to Papillary Thyroid Cancer in Chinese Han Population
}

Jie Zhu Ping Qi Zhenjie Li

Department of Endocrinology, Linyi People's Hospital, Linyi, China

\section{Key words}

Thyroid cancer $\bullet$ Single nucleotide polymorphisms $\bullet X$-ray repair cross-complementing group - Interaction • Haplotype • Obesity

\begin{abstract}
Background/Aims: To investigate the association of several single nucleotide polymorphisms (SNPs) within XRCC gene and additional gene- environment interaction with papillary thyroid cancer (PTC) risk. Methods: Testing for Hardy-Weinberg equilibrium in controls was conducted using SNPstats (online software: http://bioinfo.iconcologia.net/SNPstats). Generalized multifactor dimensionality reduction (GMDR) was used to screen the best interaction combination among 5 SNPs within XRCC gene and obesity. Results: Logistic regression analysis showed that the $C$ allele of rs861539 and T allele of rs 1799782 were associated with increased PTC risk Adjusted ORs (95\%CI) were 1.65 (1.23-2.12) and 1.61 (1.20-2.04). However There was no relation of rs 25489 Rs 25487 and rs 13181 with PTC. The cross-validation consistency and the testing accuracy for each of the models were determined by GMDR analysis. One two-locus model (rs1799782 and obesity) had a testing accuracy of $62.11 \%$ Which was significant at the $p<0.01$ level. The $D^{\prime}$ value between rs1799782 and rs13181 within ERCC1 gene was more than 0.75 (0.825). So haplotype analysis was just conducted for rs1799782 and rs13181 using the SHEsis online haplotype analysis software. In all samples The haplotype C- A was observed most frequently in two groups With $49.46 \%$ and $55.79 \%$ in the PTC patients and controls Respectively. The results also indicated that haplotype T- $C$ was significantly associated with increased PTC risk. Conclusion: The $\mathrm{C}$ allele of rs861539 and T allele of rs1799782 Interaction between rs1799782 and obesity and haplotype T- C were all associated with increased PTC risk.
\end{abstract}




\section{Cellular Physiology Cell Physiol Biochem 2018;49:638-644 and Biochemistry Published online:30 August, $2018 \begin{aligned} & \text { DOI: } 2018 \text { The Author(s). Published by S. Karger AG, Basel } \\ & \text { www.karger.com/cpb }\end{aligned}$ \\ Zhu et al.: XRCC1 Gene, Obesity and Thyroid Cancer}

\section{Introduction}

Thyroid cancer (TC) is the most common endocrine malignancy that accounts for $1 \%$ of all cancers, about $95 \%$ of endocrine cancers and $60 \%$ of all death from endocrine [1, 2]. Clinically, TC could be further divided into 4 forms: papillary thyroid carcinoma (PTC), follicular thyroid carcinoma (FTC), medullary TC (MTC), and anaplastic TC (ATC) [2, 3]. PTC is the main subtype of thyroid tumor and occurred usually in the women in the age group from 20 to 50 years, accounts for 75 to $85 \%$ among all TC patients [4]. In China, the TC incidence was increased 2.35 times from 1988 to 2009, with an average annual increase of $5.92 \%$. Moreover, the female TC incidence has been ranked among the top 10 cancer profile between 2005 and 2010 [5, 6]. To date, the molecular mechanism underlying this disease remain largely unknown. Generally, the pathological mechanism of PTC is considered as a complex process, which is caused mainly by the combined action of environmental and genetic factors $[7,8]$.

X-ray repair cross-complementing group 1 (XRCC1) protein functions in a complex with many other components to facilitate BER and single-strand break-repair processes, and it plays an important role in base excision repair (BER) and single-strand breaks repair (SSBR), upon exposure to endogenous reactive oxygen species, ionising radiation or alkylating agents $[9,10]$. Recently, two studies have reported associations of between XRCC1 and XRCC3 gene polymorphisms and risk of TC $[11,12]$, but they concluded inconsistent results. In addition, increasing evidence suggests that combination of both genetic and environmental risk determinants contribute to the development and progression of PTC. But to date, less study focused on the impact of gene- environment interaction on PTC risk. So the present study evaluates the influence of several single nucleotide polymorphisms (SNPs) within XRCC gene, and possible gene- environment interaction on PTC risk.

\section{Materials and Methods}

\section{Subjects}

A total of 458 PTC patients meet the standards were selected from our Hospital. PTC patients were confirmed by two thyroid pathologist independently through histopathological examination according to the World Health Organization standards. None of the participants had history of other cancer and received chemotherapy or radiotherapy. All the recruited subjects were Han Chinese with no genetic relationship with each other. Control subjects were those without any type cancer and matched to case patients (nearly $1: 1$ ) on the basis of their age ( \pm 5 years). Obesity was defined as BMI $\geq 28 \mathrm{~kg} / \mathrm{m}^{2}$. At recruitment, written informed consent was obtained from each subject.

\section{Genomic DNA extraction and genotyping}

All SNPs were selected based on the NCBI database (http://www.ncbi.nlm.nih.gov/projects/SNP) according to the following criteria: 1) the minor allele frequency reported in HapMap was more than $5 \%$; 2) locating in the promoter region and 3' -and 5' -untranslated region; and 3) not included in the published GWAS study. Blood samples (3.0 ml) from all participants were collected. Genomic DNA from participants was extracted from EDTA-treated whole blood, using the DNA Blood Mini Kit (Qiagen, Hilden, Germany) according to the manufacturer's instructions and stored at $-20^{\circ} \mathrm{C}$ until use. The genotyping for the selected five SNPs was conducted using polymerase Chain Reaction (PCR)-based Restriction Fragment Length Polymorphism (RFLP). The nucleotide sequence of primers and description for the 5 SNPs were shown in Table 1. The amplification conditions were used as follows: one initial denaturation step at $95^{\circ} \mathrm{C}$ for 5 min, then 30 cycles of $94^{\circ} \mathrm{C}$ for $0.5 \mathrm{~min}, 60^{\circ} \mathrm{C}$ for $0.5 \mathrm{~min}$ and $72^{\circ} \mathrm{C}$ for $1 \mathrm{~min}$, at last $72^{\circ} \mathrm{C}$ for $10 \mathrm{~min}$.

\section{Statistical analysis}

The statistical difference between cases and controls was analyzed by Chi-squared test for percentages calculated for categorical variables for normally distributed continuous variables, and by student test for the means and standard deviations (SDs) calculated for normally distributed continuous variables. Testing for 


\begin{tabular}{|c|c|}
\hline Cellular Physiology & Cell Physiol Biochem 2018;49:638-644 \\
\hline and Biochemistry & \begin{tabular}{l|l} 
DOI: 10.1159/000493027 \\
Published online: 30 August, 2018 & $\begin{array}{l}\text { O } 2018 \text { The Author(s). Published by S. Karger AG, Basel } \\
\text { www.karger.com//cpb }\end{array}$
\end{tabular} \\
\hline
\end{tabular}

Table 1. Description and primer sequences designed for sequencing 5 SNPs

\begin{tabular}{|c|c|c|c|c|}
\hline SNPs & Chromosome & Functional Consequence & $\begin{array}{l}\text { Major/ } \\
\text { minor } \\
\text { alleles }\end{array}$ & Primer $\left(5^{\prime} \rightarrow 3^{\prime}\right)$ \\
\hline $\begin{array}{l}\text { ERCC1-194 } \\
\text { (Arg>Trp) } \\
\text { rs1799782 }\end{array}$ & $19: 43553422$ & Missense & $\mathrm{C} / \mathrm{T}$ & $\begin{array}{c}\text { Forward: } 5^{\prime}- \\
\text { GCCAGGGCCCCTCCTTCAA -3' } \\
\text { Reverse: 5'- } \\
\text { TACCCTCAGACCCACGAGT-3' }\end{array}$ \\
\hline $\begin{array}{l}\text { ERCC1-280 } \\
\text { (Arg>His) } \\
\text { rs25489 }\end{array}$ & $19: 43552260$ & Missense & $\mathrm{G} / \mathrm{A}$ & $\begin{array}{c}\text { Forward: 5'- } \\
\text { CAGTGGTGCTAACCTAATC-3' } \\
\text { Reverse: 5'-AGTA- } \\
\text { GTCTGCTGGCTCTGG-3' }\end{array}$ \\
\hline $\begin{array}{l}\text { ERCC1-399 } \\
\text { (Arg>Gln) } \\
\text { rs25487 }\end{array}$ & $19: 43551574$ & Missense & $\mathrm{G} / \mathrm{A}$ & $\begin{array}{c}\text { Forward: 5'- } \\
\text { CAGTGGTGCTAACCTAATC-3' } \\
\text { Reverse: 5'- } \\
\text { AGTAGTCTGCTGGCTCTGGG-3' }\end{array}$ \\
\hline $\begin{array}{l}\text { ERCC2- } \\
\text { Lys751Gln } \\
\text { rs13181 }\end{array}$ & 19:45351661 & $\begin{array}{l}\text { Downstream variant } 500 \mathrm{~B}, \\
\text { missense, nc transcript } \\
\text { variant }\end{array}$ & $\mathrm{A} / \mathrm{C}$ & $\begin{array}{c}\text { Forward: 5'- } \\
\text { GCCCGCTCTGGATTATACG-3' } \\
\text { Reverse: 5'- } \\
\text { CTATCATCTCCTGGCCCCC-3' }\end{array}$ \\
\hline $\begin{array}{l}\text { XRCC3-241 } \\
\text { (Thr>Met } \\
\text { rs861539 }\end{array}$ & 14:103699416 & Intron variant, missense & $\mathrm{T} / \mathrm{C}$ & $\begin{array}{c}\text { Forward: } 5^{\prime}- \\
\text { GGTCGAGTGACAGTCCAAAC-3' } \\
\text { Reverse: } \text { 5' }^{\prime} \text { - TGCAACGGC } \\
\text { TGAGGGTCTT-3' }\end{array}$ \\
\hline
\end{tabular}

Hardy-Weinberg equilibrium in controls was conducted using SNPstats (online software: http://bioinfo.iconcologia. net/SNPstats). Generalized multifactor dimensionality reduction (GMDR) was used to screen the best interaction combination among 5 SNPs within XRCC gene and obesity. All reported $p$-values were two-tailed, and those less than 0.05 were considered statistically significant.

\section{Results}

Comparison of case and control groups in different demographic characteristics and prevalence of systemic diseases were shown in Table 2. A total of 918 participants were selected, including 458 patients with PTC and 460 control participants. The mean age of all participants is $58.9 \pm 12.8$ years. No significant difference in the parameters of gender and mean age were observed between these two groups (both $\mathrm{P}>0.05$ ). The TSH levels of the case group were evidently different in comparison to the control group (both $\mathrm{P}<0.05$ ). In addition, the rates for obesity, current or ex-smokers and current or ex-drinkers were higher in cases than controls.

In our study, all genotypes are distributed according to Hardy-Weinberg equilibrium in controls. The frequencies for the T allele of rs1799782 were $29.9 \%$ in cases, and $19.9 \%$ in controls, which differed significantly between the case group and the control group. The
Table 2. Comparison of case and control groups in different demographic characteristics

\begin{tabular}{|c|c|c|c|}
\hline Variables & $\begin{array}{l}\text { Case group } \\
\qquad(n=458)\end{array}$ & $\begin{array}{l}\text { Control group } \\
\qquad(n=460)\end{array}$ & P-values \\
\hline Males, N (\%) & $286(62.4)$ & $279(60.6)$ & 0.576 \\
\hline Age (year), (Means \pm SD) & $58.4 \pm 12.6$ & $59.5 \pm 13.1$ & 0.195 \\
\hline Obesity (BMI $\geq 28$ kg/m²), N (\%) & $147(32.1)$ & $108(23.5)$ & 0.00356 \\
\hline Current or ex-smokers, N (\%) & $132(28.8)$ & $91(19.8)$ & 0.0014 \\
\hline Current or ex-drinkers, N (\%) & $191(41.7)$ & $153(33.3)$ & 0.0082 \\
\hline Family history of cancer, N (\%) & $47(10.3)$ & - & \\
\hline \multicolumn{4}{|l|}{ TSH level } \\
\hline$>0.3 \mathrm{mIU} / \mathrm{L}$ & $47(10.3)$ & $31(6.7)$ & $<0.0001$ \\
\hline $0.3-3.0 \mathrm{mIU} / \mathrm{L}$ & $298(65.1)$ & 379 (82.4) & \\
\hline$>3.0 \mathrm{mIU} / \mathrm{L}$ & $113(24.7)$ & $50(10.9)$ & \\
\hline \multicolumn{4}{|l|}{ Mass size, $\mathrm{cm}$} \\
\hline$<1$ & $273(59.6)$ & & \\
\hline$\geq 1$ & $185(40.4)$ & & \\
\hline
\end{tabular}




\section{Cellular Physiology Cell Physiol Biochem 2018;49:638-644 and Biochemistry Published online:30 August, $2018 \begin{aligned} & \text { DOI 10.159/3018 The Author(s). Published by S. Karger AG, Basel } \\ & \text { www.karger.com/cpb }\end{aligned}$ Zhu et al.: XRCC1 Gene, Obesity and Thyroid Cancer}

frequencies for the $\mathrm{C}$ allele of rs 861539 were $31.7 \%$ in cases, and $21.4 \%$ in controls, which also differed significantly between the case group and the control group. Logistic regression analysis showed that the $\mathrm{C}$ allele of rs861539 and $\mathrm{T}$ allele of rs1799782 were associated with increased PTC risk, adjusted ORs (95\%CI) were 1.65 (1.23-2.12) and 1.61 (1.20-2.04). However, there was no relation of rs25489, rs25487 and rs13181 with PTC. (Table 3)

As shown in Table 4 , the cross-validation consistency and the testing accuracy for each of the models were determined by GMDR analysis. One twolocus model (rs1799782 and obesity) had a testing accuracy of $62.11 \%$, which was significant at the $\mathrm{p}<$ 0.01 level. Therefore, in the overall multi-dimensional model, regardless of how the data were divided, this best model had the highest crossvalidation consistency. It provided evidence of geneobesity interaction effects. The analysis indicated that obesity influenced the thyroid cancer risk depending on the genotypes at each of the other loci.

Pairwise LD analysis among five SNPs was measured, and we found that just the $D^{\prime}$ value between rs1799782 within ERCC1 gene and rs13181

Table 3. Genetic risk estimation for 5 target SNPs within XRCC gene and PTC. *Adjusted for age, gender, BMI

\begin{tabular}{|c|c|c|c|c|c|}
\hline \multirow{2}{*}{ SNP } & \multirow{2}{*}{ Genotypes or Alleles } & \multicolumn{2}{|c|}{ Frequencies N (\%) } & \multirow{2}{*}{ OR(95\%CI)* } & \multirow{2}{*}{ HWE test for controls } \\
\hline & & Controls $(n=460)$ & Cases $(\mathrm{n}=458)$ & & \\
\hline \multicolumn{6}{|c|}{ ERCC1-194 (ArrsTrp),rs1799782 } \\
\hline & $\mathrm{CC}$ & $299(65.0)$ & $228(49.8)$ & 1.00 (ref) & 0.266 \\
\hline & Ст & $139(30.2)$ & $184(40.2)$ & $1.49(1.15-1.87)$ & \\
\hline & TT & $22(4.9)$ & $46(10.0)$ & $2.02(1.31-2.76)$ & \\
\hline & $\mathrm{CT}+\mathrm{TT}$ & $161(35.0)$ & $230(50.2)$ & $1.61(1.20-2.04)$ & \\
\hline & Allele, T (\%) & $183(19.9)$ & $274(29.9)$ & & \\
\hline \multicolumn{6}{|c|}{ ERCC1- 280 (Arg>His), rs25489 } \\
\hline & GG & $265(57.6)$ & $240(52.4)$ & 1.00 (ref) & 0.235 \\
\hline & GA & $162(35.2)$ & $173(37.8)$ & $1.24(0.81-1.83)$ & \\
\hline & AA & $33(7.2)$ & $45(9.8)$ & $1.57(0.75-2.40)$ & \\
\hline & $\mathrm{GA}+\mathrm{AA}$ & $195(42.4)$ & $218(47.6)$ & $1.26(0.79-1.99)$ & \\
\hline & Allele, A (\%) & $228(24.8)$ & $263(28.7)$ & & \\
\hline \multicolumn{6}{|c|}{ ERCC1-399 (Arg>Gln), rs25487 } \\
\hline & GG & $295(64.1)$ & $256(55.9)$ & 1.00 (ref) & 0.684 \\
\hline & GA & $145(31.5)$ & $166(36.2)$ & $1.36(0.92-1.88)$ & \\
\hline & $\mathrm{AA}$ & $20(4.4)$ & $36(7.9)$ & $1.52(0.87-2.11)$ & \\
\hline & $\mathrm{GA}+\mathrm{AA}$ & $165(35.9)$ & $202(44.1)$ & $1.40(0.90-1.94)$ & \\
\hline & Allele, A (\%) & $185(20.1)$ & $238(26.0)$ & & \\
\hline \multicolumn{6}{|c|}{ ERCC2- Lys751Gin, rs13181 } \\
\hline & AA & $270(58.7)$ & $241(52.6)$ & 1.00 (ref) & 0.451 \\
\hline & $\mathrm{AC}$ & $161(35.0)$ & $179(39.1)$ & $1.23(0.95-1.61)$ & \\
\hline & $\mathrm{CC}$ & $29(6.3)$ & $38(8.3)$ & $1.35(0.87-1.86)$ & \\
\hline & $\mathrm{AC}+\mathrm{CC}$ & $190(41.3)$ & $217(47.4)$ & $1.27(0.93-1.66)$ & \\
\hline & Allele, C (\%) & $219(23.8)$ & $255(27.8)$ & & \\
\hline \multicolumn{6}{|c|}{ XRCC3-241 (Thr>Met), rs861539 } \\
\hline & $\mathrm{TT}$ & $290(63.0)$ & $219(47.8)$ & $1.00(\mathrm{ref})$ & 0.102 \\
\hline & $\mathrm{TC}$ & $143(31.1)$ & $188(41.0)$ & $1.49(1.25-1.87)$ & \\
\hline & CC & $27(5.9)$ & $51(11.1)$ & $2.10(1.41-2.86)$ & \\
\hline & $\mathrm{TC}+\mathrm{CC}$ & $170(37.0)$ & $239(52.2)$ & $1.65(1.23-2.12)$ & \\
\hline & Allele, C (\%) & $197(21.4)$ & $290(31.7)$ & & \\
\hline
\end{tabular}

Table 4. GMDR analysis for the best interaction combination models. *Adjusted for age, gender, BMI, alcohol drinking and smoking. ${ }^{* *}$ Adjusted for age, gender, alcohol drinking and smoking

\begin{tabular}{|c|c|c|c|c|}
\hline $\begin{array}{l}\text { Locus } \\
\text { no. }\end{array}$ & Best combination & $\begin{array}{c}\text { Cross-validation } \\
\text { consistency }\end{array}$ & $\begin{array}{c}\text { Testing } \\
\text { accuracy }\end{array}$ & $\begin{array}{c}\mathrm{p}- \\
\text { values }\end{array}$ \\
\hline \multicolumn{5}{|c|}{ Gene- gene interactions ${ }^{*}$} \\
\hline 2 & rs1799782 × rs861539 & $9 / 10$ & 0.5399 & 0.0547 \\
\hline 3 & rs1799782 × rs $861539 \times$ rs 25489 & $9 / 10$ & 0.4958 & 0.1719 \\
\hline 4 & rs $1799782 \times$ rs $861539 \times$ rs25489 ×rs13181 & $7 / 10$ & 0.4958 & 0.3770 \\
\hline 5 & $\begin{array}{l}\text { rs } 1799782 \times \text { rs861539 } \times \text { rs } 25489 \times \text { rs } 13181 \times \\
\text { rs } 25487\end{array}$ & $6 / 10$ & 0.5399 & 0.4258 \\
\hline \multicolumn{5}{|c|}{ Gene- obesity interactions ${ }^{* *}$} \\
\hline 2 & rs1799782 $\times$ obesity & $9 / 10$ & 0.6011 & 0.0010 \\
\hline 3 & rs1799782 × rs861539 ×obesity & $7 / 10$ & 0.5399 & 0.3770 \\
\hline 4 & rs1799782 × rs861539 × rs25489 × obesity & $6 / 10$ & 0.4958 & 0.4258 \\
\hline 5 & $\begin{array}{l}\operatorname{rs} 1799782 \times \operatorname{rs} 861539 \times \operatorname{rs} 25489 \times \text { rs } 13181 \times \\
\text { obesity }\end{array}$ & $3 / 10$ & 0.4958 & 0.9893 \\
\hline 6 & $\begin{array}{c}\text { rs } 1799782 \times \text { rs } 861539 \times \text { rs } 25489 \times \text { rs } 13181 \times \\
\text { rs } 25487 \times \text { obesity }\end{array}$ & $5 / 10$ & 0.4958 & 0.6230 \\
\hline
\end{tabular}


Table 5. Haplotype analysis on association of XRCC1 gene and PTC risk. *Adjusted for gender, age, smoking, alcohol drinking and BMI

\begin{tabular}{lcccc}
\hline \multirow{2}{*}{ Haplotypes (rs1799782andrs13181) } & \multicolumn{2}{c}{ Frequencies } & \multirow{2}{*}{ OR $(95 \% \mathrm{Cl})$} & \multirow{2}{*}{ p-values $^{*}$} \\
\hline C- A & 0.4946 & 0.5579 & 1.00 & -- \\
C- C & 0.2346 & 0.2282 & $1.35(0.72-2.02)$ & 0.462 \\
T- A & 0.1981 & 0.1811 & $1.26(0.69-1.98)$ & 0.546 \\
T- C & 0.0727 & 0.0328 & $1.71(1.09-2.36)$ & $<0.001$ \\
\hline
\end{tabular}

within ERCC2 was more than 0.75 (0.825). So haplotype analysis was just conducted for rs1799782 and rs13181 using the SHEsis online haplotype analysis software. In all samples, the haplotype C- A was observed most frequently in two groups, with $49.46 \%$ and $55.79 \%$ in the PTC patients and controls, respectively. The results also indicated that haplotype T- C was significantly associated with increased PTC risk (Table 5).

\section{Discussion}

In our study, we found that the $\mathrm{C}$ allele of rs861539 and $\mathrm{T}$ allele of rs1799782 were associated with increased PTC risk. However, there was no relationship of rs25489, rs 25487 and rs13181 with PTC. The mutations in XRCC genes may cause decrease or loss of DNA repair capacity and confer the variation in development of many malignant tumors, and previously, some studies have reported that XRCC1 and XRCC3 gene polymorphisms may modify the risk for some types of cancer, such as gastric cancer [13], glioma [14], breast cancer [15] and colorectal cancer [16]. But to date, less study focused on the association between XRCC gene polymorphisms and PTC risk, especially for Chinese population, and these published literatures could not concluded a consistent result. Santos et al [17]. found that XRCC1 Arg194- Trp polymorphism was not significant associated with TC risk, but just 109 TC patients were included in this study. Sigurdson et al [18]. concluded an inverse result with our study, they suggested that XRCC1 Arg194Trp polymorphism was associated with a reduced risk of TC. And different nationalities between these two studies and our study were the main reasons for this inconsistency, and the sample size of the two studies was relatively small and was less than that in our study. Recently, Wang et al [11]. suggested that XRCC1 194 (Arg>Trp) and XRCC3 241 (Thr>Met) polymorphisms may be associated with TC risk in a Chinese population, especially in smokers and drinkers. Two recent meta-analyses demonstrated that XRCC1 Arg194Trp polymorphism conferred an increased risk for PTC $[19,20]$, which was consistent with the results obtained from current study.

Generally, the pathological mechanism of PTC is considered as a complex process, which is caused mainly by the combined action of environmental and genetic factors $[7,8]$. The main risk factors for thyroid cancer are exposure to ionizing radiation, a history of benign thyroid disease, and a family history of PTC [21, 22]. Recently, a new risk factor- overweight and obesity, expressed as a high body mass index (BMI), was considered as a possible risk factor for PTC. However, there are few reports on the relationship between obesity and PTC, and the underlying mechanism is largely unknown [23]. In this study, we found that the obesity rate was higher in cases than that in controls. So we also conducted an interaction analysis between XRCC gene and obesity. We found a significant interaction between rs1799782 and obesity, and it provided evidence of gene-obesity interaction effects. The analysis indicated that obesity influenced the thyroid cancer risk depending on the genotypes at a certain loci. To our knowledge, the present study is the first report looking for a possible impact of XRCC gene- obesity interaction on PTC risk. We also conducted haplotype analysis for SNPs (rs1799782 and rs13181), the D' value for which was more than 0.75, and the results also indicated that haplotype T- C was significantly associated with increased PTC risk. 


\section{Cellular Physiology Cell Physiol Biochem 2018;49:638-644 \begin{tabular}{l|l|l} 
DOI: 10.1159/000493027 & $\begin{array}{l}\text { O 2018 The Author(s). Published by S. Karger AG, Basel } \\
\text { www.karger.com/cpb }\end{array}$ \\
\hline
\end{tabular} \\ Zhu et al:: XRCC1 Gene, Obesity and Thyroid Cancer}

There several limitations in our study. Firstly, the sample size for this study was relatively small, although it has met the requirement. Secondly, the PTC patients were no divided into different subtype, to explore the impact of this gene on different subtype of PTC. Thirdly, the demographical characteristics of thyroid cancer included $62.4 \%$ of male patients. However, thyroid cancer is reported to be much higher, i.e. three times in females compared to males, so the selection bias may existed in this study, however, this was a case- control study, and the controls have been selected scientifically.

\section{Conclusion}

We found that the $\mathrm{C}$ allele of rs861539 and T allele of rs1799782, interaction between rs1799782 and obesity and haplotype T- C were all associated with increased PTC risk.

\section{Acknowledgements} study.

We appreciate the cooperation of the families and individuals who cooperated in this

\section{Disclosure Statement}

The authors declare to have no competing interests.

\section{References}

1 Su JJ, Hui LZ, Xi CJ, Su GQ: Correlation analysis of ultrasonic characteristics, pathological type, and molecular markers of thyroid nodules. Genet Mol Res 2015;14:9-20.

2 Jemal A, Siegel R, Xu J, Ward E: Cancer statistics, 2010. CA Cancer J Clin 2010;60:277-300.

-3 Mazzaferri EL: An overview of the management of papillary and follicular thyroid carcinoma. Thyroid 1999;9:421-427.

-4 He H, Bronisz A, Liyanarachchi S, Nagy R, Li W, Huang Y, Akagi K, Saji M, Kula D, Wojcicka A, Sebastian N, Wen B, Puch Z, Kalemba M, Stachlewska E, Czetwertynska M, Dlugosinska J, Dymecka K, Ploski R, Krawczyk M, et al.: SRGAP1 is a candidate gene for papillary thyroid carcinoma susceptibility. J Clin Endocrinol Metab 2013;98:E973-980.

5 Sun J, Xu X, Cai Q: Epidemiological Study on Thyroid Cancer in China. China Cancer 2013;9:690-693.

-6 Chen W, Zheng R, Zhang S: Cancer Incidence, Mortality and Trend in China. Sci Technol Rev 2014;32:65-71.

$>7$ Koea JB, Shaw JH: Parathyroid cancer: biology and management Surg Oncol 1999;8:155-165.

8 Huang RX, Yang F: RET polymorphisms might be the risk factors for thyroid cancer. Int J Clin Exp Pathol 2015;8:5793-5797.

-9 Duell EJ, Millikan RC, Pittman GS, Winkel S, Lunn RM, Tse CK, Eaton A, Mohrenweiser HW, Newman B, Bell DA: Polymorphisms in the DNA repair gene XRCC1 and breast cancer. Cancer Epidemiol Biomark Prev 2001;10:217-222.

10 Thompson LH, West MG: XRCC1 keep DNA from getting stranded. Mutat Res 2000;459:1-18.

11 Wang X, Zhang K, Liu X, Liu B, Wang Z: Association between XRCC1 and XRCC3 gene polymorphisms and risk of thyroid cancer. Int J Clin Exp Pathol 2015;8:3160-3167.

12 Yan L, Li Q, Li X, Ji H, Zhang L: Association Studies Between XRCC1, XRCC2, XRCC3 Polymorphisms and Differentiated Thyroid Carcinoma. Cell Physiol Biochem 2016;38:1075-1084.

13 Zhao DY, Cheng L, Yu J, Shen H: XRCC1 genetic polymorphism Arg339Gln, Arg194Trp, Arg280- His and gastric cancer risk: an evidence based decision. Cancer Biomark 2014;14:449-456.

14 Xu C, Chen P, Liu W, Gu AH, Wang XR: Association between the XRCC1 Arg194Trp polymorphism and glioma risk: an updated meta-analysis. Asian Pac J Cancer Prev 2014;15:7419-7424. 


\section{Cellular Physiology Cell Physiol Biochem 2018;49:638-644 \begin{tabular}{l|l} 
DOI: 10.1159/000493027 & $\begin{array}{l}\text { O 2018 The Author(s). Published by S. Karger AG, Basel } \\
\text { www.karger.com/cpb }\end{array}$
\end{tabular} \\ Zhu et al.: XRCC1 Gene, Obesity and Thyroid Cancer}

15 Qureshi Z, Mahjabeen I, Baig R, Kayani M: Correlation between Selected XRCC2, XRCC3 and RAD51 Gene Polymorphisms and Primary Breast Cancer in Women in Pakistan. Asian Pac J Cancer Prev 2014;15:1022510229.

16 Nissar S, Sameer AS, Lone TA, Chowdri NA, Rasool R: XRCC3 Thr241Met Gene Polymorphism and Risk of Colorectal Cancer in Kashmir: a Case Control Study. Asian Pac J Cancer Prev 2014;15:9621-9625.

17 Santos LS, Branco SC, Silva SN, Azevedo AP, Gil OM, Manita I, Ferreira TC, Limbert E, Rueff J, Gaspar JF: Polymorphisms in base excision repair genes and thyroid cancer risk. Oncol Rep 2012;28:1859-1868.

18 Sigurdson AJ, Land CE, Bhatti P, Pineda M, Brenner A, Carr Z, Gusev BI, Zhumadilov Z, Simon SL, Bouville A, Rutter JL, Ron E, Struewing JP: Thyroid nodules, polymorphic variants in DNA repair and RET-related genes, and interaction with ionizing radiation exposure from nuclear tests in Kazakhstan. Radiat Res 2009;171:77-88.

19 Wang C, Ai Z: Association of XRCC1 polymorphisms with thyroid cancer risk. Tumour Biol 2014;35:47914797.

20 Du Y, Han LY, Li DD, Liu H, Gao YH, Sun DJ: Associations between XRCC1 Arg399Gln, Arg194Trp, and Arg280His polymorphisms and risk of differentiated thyroid carcinoma: a meta-analysis. Asian Pac J Cancer Prev 2013;14:5483-5487.

-21 Imaizumi M, Usa T, Tominaga T, Neriishi K, Akahoshi M, Nakashima E, Ashizawa K, Hida A, Soda M, Fujiwara S, Yamada M, Ejima E, Yokoyama N, Okubo M, Sugino K, Suzuki G, Maeda R, Nagataki S, Eguchi K: Radiation dose-response relationships for thyroid nodules and autoimmune thyroid diseases in Hiroshima and Nagasaki atomic bomb survivors 55-58 years after radiation exposure. JAMA 2006;295:1011-1022.

-22 Preston-Martin S, Franceschi S, Ron E, Negri E: Thyroid cancer pooled analysis from 14 case-control studies: what have we learned? Cancer Causes Control 2003;14:787-789.

-23 Rinaldi S, Lise M, Clavel-Chapelon F, Boutron-Ruault MC, Guillas G, Overvad K, Tjønneland A, Halkjær J, Lukanova A, Kaaks R, Bergmann MM, Boeing H, Trichopoulou A, Zylis D, Valanou E, Palli D, Agnoli C, Tumino R, Polidoro S, Mattiello A, et al.: Body size and risk of differentiated thyroid carcinomas: findings from the EPIC study. Int J Cancer 2012;131:E1004-1014. 